\title{
Twórczy potencjał Internetu w zakresie upowszechniania kultury. Blogi o muzyce poważnej
}

\begin{abstract}
Abstrakt
W niniejszym artykule Internet przedstawiony jest z punktu widzenia potencjału pobudzania kreatywności w zakresie upowszechniania sztuki. Z licznych przejawów upowszechniania sztuki $\mathrm{w}$ Internecie do analizy wybrano blogi na temat muzyki poważnej. Artykuł składa się z dwóch części: w pierwszej z nich autorka podejmuje próbę zdefiniowania twórczego potencjału Internetu w zakresie upowszechniania kultury przez pryzmat konkretnych czynników. Korzysta przy tym z istniejących teorii klimatu twórczego oraz środowiskowych stymulatorów i inhibitorów twórczości. W drugiej części artykułu wyróżnione czynniki znajdują zastosowanie w badaniu wybranych blogów o muzyce poważnej. Badania pozwalają zauważyć szereg różnic w stosunku do tradycyjnych form upowszechniania sztuki, a także prowadzą do wniosku, że blogi są formą tzw. twórczości codziennej, stymulowanej twórczym potencjałem Internetu.
\end{abstract}

Słowa kluczowe: pedagogika twórczości, upowszechnianie sztuki, Internet, blogi.

\section{Creative potential of the Internet in terms of popularizing art. Blogs on classical music}

\begin{abstract}
In this article, the Internet is presented from the point of view of the potential to stimulate creativity in the field of popularization of art. From numerous manifestations of popularization of art on the Internet, blogs about classical music were selected for analysis. The article consists of two parts: in the first one, the author attempts to define the creative potential of the Internet to disseminate culture through the prism of specific factors. The author uses the existing theories of creative climate and environmental stimulants and inhibitors of creativity. In the latter part, highlighted
\end{abstract}

\footnotetext{
* Uniwersytet Łódzki, Wydział Nauk o Wychowaniu, Katedra Edukacji Artystycznej i Pedagogiki Twórczości.
} 
factors find application in the study of selected blogs about classical music. The research reveals a number of differences compared to traditional forms of popularizing art, and also leads to the conclusion that blogs are a form of the so-called everyday creativity stimulated by the creative potential of the Internet.

Keywords: Pedagogy of creativity, popularizing art, the Internet, blogs.

\section{Wprowadzenie}

Analizy i badania Internetu podejmowane przez przedstawicieli wielu dyscyplin naukowych w przeważającej liczbie przypadków koncertują się na zagrożeniach rzeczywistości wirtualnej. Pozytywne opracowania dotyczą przede wszystkim edukacji (e-learning). Znacznie mniej uwagi poświęca się zagadnieniom potencjału twórczego tego medium, które mimo kilkudziesięcioletniej historii wciąż zwane jest „nowym”. Brakuje opracowań prezentujących Internet jako środowisko o określonym potencjale twórczym.

Celem niniejszego artykułu jest analiza środowiska Internetu pod kątem potencjału pobudzania kreatywności w zakresie upowszechniania sztuki. Z licznych przejawów upowszechniania sztuki w Internecie do analizy wybrano blogi na temat muzyki poważnej. Artykuł składa się z dwóch części: w pierwszej z nich autorka podejmuje próbę zdefiniowania twórczego potencjału Internetu w zakresie upowszechniania kultury przez pryzmat konkretnych czynników. Czyni to, odnosząc się do istniejących teorii klimatu twórczego oraz środowiskowych stymulatorów i inhibitorów twórczości. W drugiej części artykułu wyróżnione czynniki znajdują zastosowanie w badaniu wybranych blogów o muzyce poważnej.

\section{Internet - ważne, choć już nienowe miejsce upowszechniania sztuki}

Badania Internetu między innymi dlatego są tak trudne i niejednoznaczne, że sieć globalna niezwykle szybko się zmienia. Dynamizm tych przemian nie ma sobie równych w dziejach ludzkiego komunikowania. Poziom skomplikowania relacji zachodzących $\mathrm{w}$ Internecie oraz relacji między Internetem a światem realnym na poszczególnych polach działalności człowieka sprawia, że zagadnienie to jest dużym wyzwaniem badawczym. Choć Internet w porównaniu z innymi mediami ma wyjątkowo krótką historię, w jego rozwoju zarysowują się dwie zasadnicze fazy: technologia Web 1.0 oraz technologia Web 2.0 (Sarowski 2017) ${ }^{1}$. Internet 1.0 dawał niespotykane wcześniej możliwości przekazywania informacji, dominował w nim jednak nadal jednokierunkowy model komunikacji. Fakt, iż zarządzanie treścią

1 Niekiedy wyróżnia się także Web 3.0 - sieć semantyczną oraz Web 4.0 - Internet rzeczy. 
należało do administratorów konkretnych serwisów, zbliżał model działania Internetu do modelu znanego z mediów tradycyjnych. Najważniejszą cechą Web 2.0 jest natomiast interaktywność oraz wspieranie kultury uczestnictwa, co każe postrzegać Internet $\mathrm{w}$ kontekście społecznym. Sztywny podział na nadawców i odbiorców przestał istnieć, każdy internauta może być zarówno adresatem przekazów, jak i ich nadawcą (często pełni obie te role niemal jednocześnie). Interaktywność Web 2.0 swą najpełniejszą manifestację znajduje w mediach społecznościowych, których przykładem są blogi.

Fascynujące zjawisko, jakim są blogi i blogosfera, z powodu swego dynamicznego rozwoju nie doczekało się jeszcze wyczerpującego zbadania. Blogi można rozpatrywać między innymi jako przejaw tzw. twórczości codziennej, czyli takiej, która nie owocuje powstaniem ponadczasowych dzieł artystycznych, ale ma duże znaczenie dla osoby tworzącej oraz jej najbliższego otoczenia (Modrzejewska-Świgulska 2007). Twórczość codzienna powoduje wzmocnienie sił psychicznych i fizycznych, sprzyja samorealizacji, daje motywację do wzrostu i rozwoju, dzięki czemu twórca może „wnieść określony wkład do tworzącego się świata” (tamże: 160). Omawiane tutaj blogi o sztuce plasują się w następującym zakresie tego pojęcia: „twórczość codzienna jako forma aktywności kulturowej oraz uczestnictwa w kulturze, zrywająca $\mathrm{z}$ dominacją zachowań reprodukcyjnych i recepcją dóbr kultury na rzecz ekspresji twórczej w rozmaitych formach" (tamże: 164).

Choć pedagodzy i psycholodzy poświęcają twórczości codziennej stosunkowo niewiele uwagi, ma ona duże znaczenie, gdyż dotyczy znacznie większej niż twórczość elitarna grupy ludzi - potencjalnie każdego. W czasach obecnych, w dobie rozwiniętego Internetu, pojęcie twórczości codziennej nabiera nowego wymiaru, gdyż Internet ułatwia dzielenie się swoją „małą twórczością” z innymi, także z ludźmi odległymi terytorialnie i kulturowo. Twórczość taka może mieć zatem znacznie większy zasięg i większy wpływ na odbiorców.

Aktywność twórcza, choć jest potencjalnie dostępna każdemu, nie u każdego przejawia się w takim samym stopniu. Jej rozwój zależy od wielu czynników, wśród których najważniejsze to: predyspozycje genetyczne, określone cechy osobowości i zaangażowanie $\mathrm{w}$ podejmowane działania. Wszystkie te czynniki mają charakter wewnętrzny, zależny od jednostki. Istnieją jednak także czynniki zewnętrzne, związane ze środowiskiem. Może ono działać stymulująco lub hamująco i w związku z tym wyróżnia się środowiskowe stymulatory i inhibitory twórczości (Szmidt 2013: 66). W ostatnich latach jednym z najważniejszych środowisk życia stał się Internet.

Rozwój Internetu sprawił, że do przestrzeni wirtualnej w dużym stopniu przenoszą się aktywności znane z życia offline. W sieci zyskują one nowe formy, które niekiedy funkcjonują zamiast, zwykle jednak - obok form znanych i popularnych wcześniej. W Internecie odbywa się między innymi szereg działań związanych z upowszechnianiem kultury. Są one podejmowane przez instytucje kultury, takie jak filharmonie, teatry, muzea, domy kultury, ale także przez osoby prywatne, dla 
których w wielu przypadkach jest to działalność amatorska. Upowszechnianie sztuki za Stefanem Szumanem (1975) jest tu rozumiane jako działanie polegające na

zbliżaniu jej szerokim masom społeczeństwa zarówno przez udostępnianie licznych najlepszych dzieł sztuki wielu odbiorcom, jak też przez uczynienie ich przystępnymi, co powinno w rezultacie rozwinąć umiłowanie sztuki, umiejętność radowania się nią, rozumienia jej oraz zapotrzebowania na nią u coraz szerszej rzeszy odbiorców (tamże: 124).

Od czasów konceptualizacji tej teorii minęło niemal 60 lat i choć słownictwo stosowane w dyskursie naukowym zmieniło się znacznie, podstawowa idea głoszona przez Szumana pozostaje wciąż aktualna. Przypomnijmy, że na upowszechnianie sztuki składają się dwa procesy: udostępnianie - „czynność uobecniania komuś dzieł sztuki, czyli wprowadzania ich w konkretnej postaci oryginału, lub jego faksymile w zasięg wzrokowego czy też słuchowego odbioru osoby, którą «wychowujemy przez sztukę»”, oraz uprzystępnianie dzieł sztuki, czyli „czynienie ich przystępnymi dla doznań i przeżyć odbiorcy” (tamże: 124). Właśnie za sprawą Internetu problem udostępniania dzieł sztuki niemal przestał istnieć: w sieci znajdują się filmy, książki (w formie e-booków i audiobooków), nagrania dźwiękowe, reprodukcje dzieł sztuki, a muzea z niemal każdego zakątka świata oferują wirtualne zwiedzanie. Powoduje to fałszywe przekonanie, że w zakresie upowszechniania sztuki celowe działania są już niepotrzebne. Nie jest to prawdą, gdyż wyzwanie stanowi wciąż drugi z wyróżnionych przez Szumana procesów: uprzystępnianie dzieł sztuki.

Autorka niniejszego artykułu wychodzi z założenia, że upowszechnianie kultury może być działaniem twórczym. Nie tylko dlatego, że twórcza jest sama sztuka, ale dlatego, że upowszechnianie wymaga elastyczności myślenia, wrażliwości, otwartości na drugiego człowieka i jego potrzeby. Starania o upowszechnianie sztuki wysokiej mogą stymulować do podejmowania $\mathrm{w}$ tym celu różnych form twórczości codziennej. Jedną z takich form stają się blogi, które mogą być przykładem działań twórczych zarówno w zakresie samego pisarstwa - tworzenia tekstu, jak i w zakresie działań dodatkowych, takich jak: promocja, zdobywanie czytelnika, utrzymywanie kontaktu z nim, aktywność poza Internetem. Spotykane niekiedy stwierdzenie, iż blog jest internetową formą pamiętnika, to duże uproszczenie, gdyż uwypukla literacki, pisarski aspekt tworzenia blogów, pomija zaś nie mniej istotny aspekt społecznościowy.

Blogi stały się nowym miejscem słuchania muzyki i dyskusji o niej, miejscem, które częściowo przejmuje zadania funkcjonujących przez wiele wieków salonów muzycznych. Zjawisko przechodzenia do przestrzeni Internetu ekskluzywnych form aktywności kulturalnej nie dotyczy jedynie muzyki; przykładowo, Aneta Bassa (2016) opisała je na podstawie blogów i portali literackich we Francji, porównując je do istniejących od wieków salonów literackich. 
Choć zdarza się, że blogi są prowadzone przez profesjonalistów, fachowców w danej dziedzinie (przykład taki zostanie omówiony poniżej), generalną zasadą jest, że prowadzą je amatorzy. To właśnie rozpowszechnienie aktywności amatorskiej i zrównanie jej pod wieloma względami z działalnością profesjonalistów jest jedną z najważniejszych cech technologii Web 2.0, cech, które u niektórych badaczy budzą entuzjazm, u innych zaś - obawy. Entuzjaści wskazują na stymulowanie aktywności użytkowników Internetu, łatwość nawiązywania kontaktów, możliwość angażowania się w akcje społeczne czy kulturalne. Przeciwnicy obawiają się braku odpowiedzialności za słowo, rozhamowania społecznego i dyletantyzmu. Do tego grona należy Andrew Keen (2007), który swoje ostrzeżenia dotyczące skutków działania sieci zawarł w słynnej książce Kult amatora. Jak Internet niszczy kulturę. Autor ostrzega, że szerzący się w Internecie tzw. kult amatorszczyzny powadzi do obniżenia poziomu wytworów, niedoceniania profesjonalnego przygotowania i wykształcenia oraz do rozpowszechniania informacji niesprawdzonych, często nieprawdziwych:

Przed epoką Web 2.0 naszą kulturę intelektualną stymulowało staranne kolekcjonowanie prawdy - poprzez profesjonalnie redagowane książki i materiały źródłowe, gazety, radio i telewizję. Ale w miarę jak wszystkie informacje stają się cyfrowe i zdemokratyzowane oraz dostępne w sposób uniwersalny i ciągły, Internet staje się medium naszej pamięci, a tam dezinformacja nigdy nie znika. W rezultacie ten zbiór informacji jest zainfekowany przez błędy i oszustwa (tamże: 84).

Choć podobne obawy wyraża wielu analityków, opinia Keena należy do skrajnie pesymistycznych, gdyż autor nie równoważy jej zaletami działalności amatorskiej. Tymczasem jej zwolennikiem był przywoływany już tu Stefan Szuman, który „dyletantyzm” cenił nie tylko ze względu na potencjał rozwijania wrażliwości twórców, ale także kształtowania kultury artystycznej społeczeństwa (Szuman 1975).

\section{Badanie Internetu w kontekście społecznych uwarunkowań twórczości - zagadnienia terminologiczne}

Badacze kreatywności i twórczości koncentrują się zwykle na osobie twórcy i procesie twórczym. Spośród czterech wymiarów twórczości - wytworu, procesu, cech osoby i czynników warunkujących (Szmidt 2007) - zdecydowanie najrzadziej badany jest ten ostatni: zewnętrzne uwarunkowania wpływające na twórcę i twórczość (istniejące opracowania tego zagadnienia koncentrują się zaś na dydaktyce). Choć nie ma wątpliwości, że impuls do tworzenia musi wypływać z wewnątrz, wiadomo też, że warunki życia i działania odgrywają w procesie twórczym 
niebagatelną rolę. Proces twórczy nie zachodzi w próżni. Temat artykułu - twórczy potencjał Internetu - nakierowuje uwagę na ten właśnie aspekt zjawiska twórczości, przy czym Internet można tu określić jako środowisko posiadające klimat o określonych cechach, wpływających na twórczość.

Wszyscy autorzy zajmujący się od strony teoretycznej społecznymi uwarunkowaniami twórczości (m.in. Stanisław Popek (2001), Roman Schulz (1990), Józefa Sołowiej (1997), Józef Kozielecki (2008), Edward Nęcka (2016)) zwracają uwagę, że czynniki wewnętrzne i zewnętrzne nierozerwalnie się ze sobą splatają. S. Popek (2001) koncentruje się na analizie warunków rodzinnych i edukacyjnych, w których wzrasta i rozwija się dziecko. R. Schulz (1990) przedstawia refleksje nad klimatem sprzyjającym twórczości w kontekście kształtowania nowoczesnego systemu wartości. E. Nęcka (2016), analizując społeczny kontekst twórczości, koncentruje się na trzech środowiskach: rodzinnym, szkolnym i miejscu pracy, wskazuje też na określone cechy całych społeczeństw. Podobnie uwarunkowaniom społecznym, a nawet szerzej biorąc - cywilizacyjnym - przygląda się J. Kozielecki (2008). J. Sołowiej (1997) wyróżnia następujące cechy społeczne sprzyjające aktywności twórczej:

- otwartość na szeroko rozumianą problematykę kulturalną, co przejawia się w dyskusjach na tematy artystyczne i naukowe prowadzonych w środkach masowego przekazu, próbach weryfikacji hipotez itp.,

- wysokie usytuowanie w systemie wartości społecznych procesu samorealizacji i rozwoju osobowego,

- wolny dostęp do instytucji oświatowych i wszelkiego rodzaju zbiorów informacji oraz dzieł,

- różnorodność bodźców kulturalnych, typowa dla krajów mieszanych etnicznie oraz grup zróżnicowanych kulturowo,

- tolerancja dla różnych stylów zachowania i poglądów, przy czym już zmniejszenie stopnia represji w społeczeństwie represyjnym może stanowić silny bodziec dla twórczości,

- współdziałanie osób wybitnych oraz społeczne uznanie dla twórczości i twórcy (tamże: 67).

Zagadnienie twórczego potencjału miejsca jest domeną psychologii organizacji, gdzie pod tym kątem analizuje się miejsce pracy, firmę czy instytucję (Karkowski, Pawłowska 2009). Większość wyznaczników tak pojmowanego miejsca nie może zostać zastosowana do Internetu, gdyż po pierwsze - nie jest on miejscem pracy, a zatem nie ma tam szefów, współpracowników, nie można mówić o planowaniu i jego efektach, po drugie zaś - nie jest miejscem o wyraźnych granicach, które mogłoby być definiowane przez określony typ zarządzania czy organizacji. Do analizy kreatywności Internetu nie da się także zastosować wskaźników używanych do oceny kreatywności szkoły, gdyż w szkole najistotniejszym czynnikiem wyzwalającym takie postawy jest nauczyciel i jego sposób działania. Maciej Kar- 
wowski (2009), autor publikacji Klimat dla kreatywności. Koncepcje, metody, badania także koncentruje się na dwóch szczególnych środowiskach: szkole i miejscu pracy. Wybór tych miejsc jest uzasadniony - tam przede wszystkim oczekuje się kreatywności, modyfikowania rzeczywistości, nowych pomysłów itd. Wydaje się, że brak analiz Internetu pod kątem jego potencjału kreatywności stanowi istotną lukę w badaniach naukowych z dziedziny psychologii twórczości i pedagogiki twórczości.

Najbardziej znaną na świecie koncepcję klimatu dla twórczości stworzył szwedzki psycholog pracy i organizacji Göran Ekvall (Isaksen, Laurel, Ekvall, Britz 2001). W odniesieniu do organizacji klimat definiowany jest jako trwałe wzory zachowań, postaw i uczuć, które charakteryzują życie w organizacji (Karwowski 2003: 230). Rzecz prosta, definicja ta nie przystaje do Internetu, choć Karwowski przyznaje, że pod kątem analizy klimatu charakteryzować można nawet społeczeństwo. Od niedawna coraz większą popularność zyskuje pojęcie „miasta kreatywnego”, które określa potencjał miasta w pobudzaniu kreatywności, co z kolei prowadzi do rozwoju tzw. przemysłów kreatywnych i przewagi technologicznej (Rogowska 2013).

Ekvall (Isaksen, Laurel, Ekvall, Britz 2001: 175) wyróżnia następujące elementy decydujące o ocenie klimatu twórczego: wyzwanie i możliwość wywierania wpływu; wolność; otwartość/zaufanie; czas na realizację pomysłów; humor i ludyczność; konflikt; wsparcie pomysłów; debata; podejmowanie ryzyka; dynamizm. Ponieważ jest to najbardziej kompletna typologia, zawierająca także inhibitor (konflikt), zdecydowano zastosować ją do analizy blogów. Najpierw określono, jaka jest specyfika przejawiania się wyszczególnionych cech klimatu twórczego w Internecie, natomiast po analizie dokumentów uszczegółowiono tę charakterystykę z punktu widzenia blogosfery. Tabele stanowią podsumowanie i syntezę treści zawartych w tekście ciągłym.

Badanie Internetu jako środowiska potencjalnie kreatywnego wymaga poczynienia istotnych zastrzeżeń. Przede wszystkim konieczna jest świadomość, że mamy tak naprawdę do czynienia z dwoma wzajemnie na siebie oddziałującymi środowiskami: oprócz Internetu jest to środowisko realne, w którym dana osoba na co dzień żyje i działa, i z tego Internetu korzysta. Środowiska te wpływają na siebie wzajemnie. Co więcej, czynniki zewnętrze podlegają modyfikacji przez osobowość jednostki. Jak wyjaśnia K. J. Szmidt (2007):

Przeszkodą dla twórczości nie jest czynnik zewnętrzny sam w sobie (...), ale formuła przekładu tego czynnika na procesy psychiczne i zachowanie jednostki. Inaczej mówiąc, to jednostka twórcza w ostateczności «decyduje», czy dany czynnik zakłóci lub zahamuje jej procesy twórcze (tamże: 198).

Twórczy potencjał Internetu - podobnie jak każdego fizycznie istniejącego miejsca - zależy od osób w nim działających. Potencjał miejsca wpływa na ludzi, ale jednocześnie jest przez nich tworzony. 


\section{Klimat twórczy offline i online}

Porównanie cech klimatu twórczego miejsca rzeczywistego $\mathrm{z}$ miejscem online prowadzi do następujących wniosków:

Tabela 1. Charakterystyka klimatu twórczego Internetu wg koncepcji klimatu dla twórczości G. Ekvalla

\begin{tabular}{|l|l|}
\hline \multicolumn{1}{|c|}{$\begin{array}{c}\text { Cecha klimatu } \\
\text { twórczego }\end{array}$} & \multicolumn{1}{|c|}{ Charakterystyka cechy ze względu na specyfikę Internetu } \\
\hline $\begin{array}{l}\text { Wyzwanie i możliwość } \\
\text { wywierania wpływu }\end{array}$ & $\begin{array}{l}\text { Potencjalne możliwości wywierania wpływu bardzo duże ze } \\
\text { względu na zróżnicowane grono odbiorców o bardzo różnorod- } \\
\text { nych poglądach. Duże wyzwanie, które może budzić nawet } \\
\text { reakcje ucieczkowe }\end{array}$ \\
\hline Wolność & $\begin{array}{l}\text { Duża sfera wolności, wynikająca z możliwości decydowania } \\
\text { o stopniu zaangażowania i ewentualnego tworzenia treści. } \\
\text { Możliwość samodzielnego ustalania proporcji między działaniami } \\
\text { odbiorcy i nadawcy (specyfika Web 2.0). Możliwość podejmowa- } \\
\text { nia aktywności niezwiązanych z życiem codziennym, dziedziną } \\
\text { pracy czy nauki, możliwość odejścia od wyborów typowych dla } \\
\text { środowiska realnego, do którego się należy }\end{array}$ \\
\hline Otwartość/zaufanie & $\begin{array}{l}\text { Niewielkie zaufanie internautów-odbiorców wobec nadawców } \\
\text { treści, o czym świadczy częsta krytyka czy wręcz ataki werbalne } \\
\text { (efekt rozhamowania społecznego). Niewielkie zaufanie nadaw- } \\
\text { ców wobec miejsca ze względu na niemożność kontrolowania } \\
\text { przepływu treści po zamieszczeniu ich w Internecie. Jednocześnie } \\
\text { obserwuje się dużą otwartość internautów ze względu na złudne } \\
\text { poczucie anonimowości }\end{array}$ \\
\hline Konflikt & $\begin{array}{l}\text { Czas niemal nieograniczony, brak terminów, zobowiązań. } \\
\text { Zagrożenie odkładaniem realizacji pomysłów w nieskończoność }\end{array}$ \\
\hline Czas na realizację \\
pomysłów
\end{tabular}




\begin{tabular}{|l|l|}
\hline Wsparcie pomysłów & $\begin{array}{l}\text { Wsparcie pomysłów może polegać na przykładzie innych, } \\
\text { motywowaniu, możliwości docierania do informacji ułatwiają- } \\
\text { cych realizację pomysłów. Poczucie wsparcia w znacznym } \\
\text { stopniu zależy od aktywności danej osoby i umiejętności wyko- } \\
\text { rzystania potencjału Internetu: braku barier czasoprzestrzen- } \\
\text { nych, możliwości kontaktowania się z ludźmi z różnych stron } \\
\text { świata, zmiany środowiska, kontaktu z mistrzem itp. }\end{array}$ \\
\hline Debata & $\begin{array}{l}\text { Częste i burzliwe debaty w Internecie na różne tematy, także } \\
\text { wśród osób niemających doświadczeń osobistych ani kompeten- } \\
\text { cji do wypowiadania się na dany temat. Niektóre osoby mogą } \\
\text { czuć się zainspirowane, inne zaś - zniechęcone }\end{array}$ \\
\hline Podejmowanie ryzyka & $\begin{array}{l}\text { Dość wysokie ryzyko z powodu wystawienia się na ocenę bardzo } \\
\text { dużego i zróżnicowanego grona odbiorców. Podczas działań } \\
\text { kreatywnych występuje także ryzyko wynikające z nieostrożnych } \\
\text { zachowań w sieci, a dodatkowo ryzyko kradzieży intelektualnej } \\
\text { (piractwo) }\end{array}$ \\
\hline Dynamizm & $\begin{array}{l}\text { Duży dynamizm wydarzeń dziejących się w Internecie, ogromna } \\
\text { nadprodukcja treści }\end{array}$ \\
\hline
\end{tabular}

Źródło: opracowanie własne na podstawie koncepcji klimatu dla twórczości G. Ekvalla (Isaksen, Laurel, Ekvall, Britz 2001).

Z powyższej analizy wynika, że twórczy potencjał Internetu jest znaczny. Oczywiście, należy pamiętać, że jest to środowisko bardzo różnorodne i w większym stopniu niż gdzie indziej możliwości kreatogenne zależą od jednostki, która z Internetu korzysta. Trzeba też zauważyć, że niemal każda cecha może być interpretowana zarówno jako stymulator, jak i inhibitor twórczości, w zależności od kontekstu. Przykładowo: anonimowość, która daje swobodę i pozwala na wyzwolenie się z nadmiernych ograniczeń, może prowadzić do rozhamowania, braku kontroli nad własnym postępowaniem, a nawet werbalnych zachowań agresywnych. Wirtualne spotkania z innymi ludźmi mogą działać motywująco, ale mogą też onieśmielać i zniechęcać do działania osoby niepewne siebie, nieśmiałe, zahamowane.

Bardziej szczegółowa charakterystyka powyższych czynników jest możliwa przy uwzględnieniu określonego typu aktywności w Internecie.

Tabela 2. Charakterystyka klimatu twórczego blogów o sztuce wg koncepcji klimatu dla twórczości G. Ekvalla

\begin{tabular}{|l|l|}
\hline \multicolumn{1}{|c|}{$\begin{array}{c}\text { Cecha klimatu } \\
\text { twórczego }\end{array}$} & \multicolumn{1}{c|}{ Charakterystyka cechy ze względu na specyfikę Internetu } \\
\hline $\begin{array}{l}\text { Wyzwanie i możliwość } \\
\text { wywierania wpływu }\end{array}$ & $\begin{array}{l}\text { Znacząca możliwość wywierania wpływu w określonej dziedzinie } \\
\text { dzięki temu, że autor bloga postrzegany jest jako autorytet }\end{array}$ \\
\hline
\end{tabular}




\begin{tabular}{|c|c|}
\hline Wolność & $\begin{array}{l}\text { Duża wolność w wyborze treści i formy jej przedstawiania, } \\
\text { możliwość eksperymentowania }\end{array}$ \\
\hline Otwartość/zaufanie & $\begin{array}{l}\text { W porównaniu z innymi środowiskami w Internecie wysokie } \\
\text { zaufanie czytelników ze względu na regularność i długotrwałość } \\
\text { relacji oraz posiadanie określonej wiedzy o autorze bloga }\end{array}$ \\
\hline $\begin{array}{l}\text { Czas na realizację } \\
\text { pomysłów }\end{array}$ & $\begin{array}{l}\text { Swoboda w określaniu czasu na realizację pomysłów, jednak } \\
\text { istnieje konieczność regularności w zamieszczaniu nowych treści, } \\
\text { narzucona formułą bloga (w odróżnieniu od innym form aktyw- } \\
\text { ności w Internecie, takich jak czaty czy fora dyskusyjne) }\end{array}$ \\
\hline Humor i ludyczność & $\begin{array}{l}\text { Stosunkowo niewielki poziom humoru i ludyczności ze względu } \\
\text { na tematykę bloga, choć możliwość wprowadzania humoru do } \\
\text { formy wypowiedzi (język) }\end{array}$ \\
\hline Konflikt & $\begin{array}{l}\text { W porównaniu z innymi środowiskami w Internecie niski poziom } \\
\text { konfliktu. Obserwowana powściągliwość w wyrażaniu odmien- } \\
\text { nych poglądów zarówno przez autorów, jak i odwiedzających } \\
\text { blogi }\end{array}$ \\
\hline Wsparcie pomysłów & $\begin{array}{l}\text { Wsparcie pomysłów możliwe na poziomie technicznym (ogólno- } \\
\text { dostępne, bezpłatne rozwiązania do tworzenia blogów). Inna mo- } \\
\text { żliwość wsparcia pomysłów związana jest z kontaktami w śro- } \\
\text { dowisku artystów i miłośników sztuki, zdobywaniem biletów lub } \\
\text { zaproszeń na wydarzenia artystyczne (jako forma zapłaty za } \\
\text { wzmiankę lub recenzję) }\end{array}$ \\
\hline Debata & $\begin{array}{l}\text { Możliwość debaty na tematy zgodne z tematyką bloga wśród } \\
\text { osób o podobnych zainteresowaniach i specjalistycznej wiedzy. } \\
\text { Stosunkowo duża otwartość internautów na osoby o odmiennych } \\
\text { poglądach }\end{array}$ \\
\hline Podejmowanie ryzyka & $\begin{array}{l}\text { Ryzyko wizerunkowe podobne jak w przypadku całego Internetu. } \\
\text { Powiększa je fakt znajomości danej osoby w środowisku realnym }\end{array}$ \\
\hline Dynamizm & $\begin{array}{l}\text { Stosunkowo duży dynamizm blogów, choć możliwe są pewne } \\
\text { różnice w zależności od autorów }\end{array}$ \\
\hline
\end{tabular}

Źródło: opracowanie własne na podstawie koncepcji klimatu dla twórczości G. Ekvalla (Isaksen, Laurel, Ekvall, Britz 2001).

\section{Blogi o sztuce jako forma upowszechniania kultury}

W celu zbadania twórczego potencjału Internetu przeprowadzono analizę blogów o muzyce poważnej, obecnych w polskim Internecie ${ }^{2}$. Wybrano metodę studium

\footnotetext{
2 Analizowano następujące blogi: https://szwarcman.blog.polityka.pl/, https://www.facebook.com/pg/ blogerka.klasycznie.muzyczna, https://po-klawiszach.blogspot.com/, /https://placowkapostepu.word press.com/
} 
przypadku, przy założeniu, że przypadkiem jest szczególny sposób upowszechniania sztuki w przestrzeni Internetu za pomocą blogów o muzyce poważnej. Na studium przypadku jako metodę wyjątkowo przydatną przy badaniu środowiska twórczego wskazuje m.in. Marta Galewska-Kustra (2007). Zastosowano analizę dokumentów zastanych: treści blogów, przy czym analizowane były zarówno wpisy osób je prowadzących, jak i komentarze. Uzupełniająco analizowano inne teksty znajdujące się w Internecie, mogące świadczyć o pozycji tych blogów i ich autorów w środowisku osób związanych ze sztuką, co pozwoliło na zarysowanie szerokiego kontekstu badanego zjawiska. Analiza dokumentów była prowadzona pod kątem występowania/niewystępowania oraz specyfiki elementów decydujących w ocenie klimatu twórczego, zgodnie z wymienionymi wyżej.

Blogi o muzyce poważnej zajmują ilościowo bardzo niewiele miejsca w bogatej i różnorodnej polskiej blogosferze. W środowisku miłośników muzyki i osób zajmujących się tą dziedziną sztuki profesjonalnie pełnią jednak ważną rolę. Do analizy wybrano następujące blogi:

- Co w duszy gra;

- Nadia Attavanti. Blogerka Klasycznie Muzyczna;

- Spacerkiem po klawiszach;

- Placówka postępu.

Podstawowym kryterium wyboru, oprócz tematyki, była aktualność bloga - musiał być „żywy”, uzupełniany aktualnymi wpisami. Pożądana była duża częstość wpisów jako gwarantująca odpowiednią ilość materiału do analizy. O wpływie na odbiorców można wnioskować na podstawie popularności, co oceniano, biorąc pod uwagę liczbę wejść i odsłon (nie wszędzie jest to widoczne). Duża liczba komentarzy świadczy zaś o aktywności odbiorców.

Dorota Szwarcman, autorka bloga „Co w duszy gra” (https://szwarcman. blog.polityka.pl/) wyróżnia się wszechstronnym wykształceniem kierunkowym i największym doświadczeniem spośród autorów blogów poddanych analizie. Jest ona jedną z najbardziej rozpoznawalnych i cenionych polskich publicystek, zajmujących się muzyką poważną. Blog jest nie tylko miejscem wyrażania poglądów przez autorkę, ale także miejscem dyskutowania, dzielenia się poglądami, twórczego fermentu. Potwierdza to przyznana dziennikarce nominacja do nagrody Gwarancja Kultury 2015, uzasadniana następująco:

za stworzenie miejsca w sieci, w którym o muzyce klasycznej dyskutuje się ze znawstwem i pasją. Miejsca na tyle uniwersalnego, że swobodnie czuje się tu wyrafinowany specjalista i odbiorca dopiero zaczynający przygodę z muzyką klasyczną. Za popularyzowanie muzyki bez uciekania się do uproszczeń i schematów (Blog Doroty Szwarcman ... 2015).

Blog jest prowadzony od maja 2007 r. Wpisy pojawiają się mniej więcej co drugi dzień, jest ich kilkanaście miesięcznie (liczba ta jest zmienna w zależności od 
intensywności wydarzeń muzycznych). Niemal pod każdym wpisem pojawiają się komentarze, na które odpowiada autorka bloga.

Dorota Szwarcman jest absolwentką Wydziału Teorii Muzyki, Kompozycji i Dyrygentury Akademii Muzycznej im. Fryderyka Chopina w Warszawie. Działalność dziennikarską prowadziła w „Ruchu Muzycznym”, „Gazecie Wyborczej”, „Wprost”, „Tygodniku Powszechnym”, „Jazz Forum”. Obecnie związana jest z tygodnikiem „Polityka”. Jest też autorką kilku książek o tematyce muzycznej. Wyróżniono ją odznaką honorową „Zasłużony dla Kultury Polskiej” (2007) oraz Medalem Stowarzyszenia Polskich Artystów Muzyków „Za Zasługi dla Muzyki Polskiej” (2007). Blog „Co w duszy gra” znajduje się na platformie polityka.pl i zawiera odniesienia do drukowanych tam artykułów, jest więc formą reklamy ze strony czasopisma. Trudno mówić o pełnej dobrowolności prowadzenia bloga przez autorkę, gdyż zapewne jest to element jej pracy $\mathrm{w}$ czasopiśmie. Zamieszczane są tu relacje i recenzje z koncertów, premier operowych, festiwali i innych znaczących wydarzeń z zakresu muzyki poważnej. Pojawiają się recenzje płyt.

Nadia Attavanti prowadzi na Facebooku profil o nazwie „Nadia Attavanti. Blogerka Klasycznie Muzyczna”, który określa następująco: „Strona o operze i muzyce klasycznej dla każdego. Bez nadęcia i snobizmu" (https://www.facebook.com/pg/ blogerka.klasycznie.muzyczna/). Stronę tę „lubi” 5481 osób (dane na 24.03.2018), obserwuje zaś - 5528 użytkowników Facebooka. Forma Facebooka ułatwia prowadzenie bloga, gdyż ten portal społecznościowy nastawiony jest na częste, regularne zamieszczanie stosunkowo krótkich wiadomości oraz komentowanie ich przez odbiorców. Każdy wpis zawiera zdjęcie lub filmik, co zwiększa prawdopodobieństwo zainteresowania się wpisem przez użytkowników Facebooka. Nadia Attavanti jest regularną bywalczynią najważniejszych wydarzeń kulturalnych w Polsce i cieszy się poważaniem nie tylko miłośników sztuki, ale także organizatorów wydarzeń kulturalnych. Została zaproszona do nagrania filmu promocyjnego festiwalu Opera Rara w styczniu 2018 r. (Festiwal Opera Rara...). W czasopiśmie o charakterze promocyjnym „Opera café”, wydawanym przez Operę Śląską w Bytomiu, opublikowano fragment napisanej przez nią na blogu recenzji przedstawienia Księżniczka czardasza (Po premierze napisano... 2018). Blogerka nowe wpisy publikuje niemal codziennie, zamieszcza dużo zdjęć. Komentarze pod wpisami mają zwykle charakter potwierdzający treść wypowiedzi.

Spacerkiem po klawiszach (http://po-klawiszach.blogspot.com/) to tytuł bloga prowadzonego przez Honoratę (tylko takie informacje o sobie udostępnia). Pierwszy wpis pochodzi z 28 stycznia 2015 r. Blog został założony w 159. rocznicę urodzin Mozarta. Autorka omawia określone gatunki utworów muzycznych, np. koncerty harfowe twórców różnych epok, przedstawia mało znanych kompozytorów, takich jak Franciszek Lessel (wpis z dnia 13.03.2018), zachęca do wysłuchania utworów, które wyszperała w sieci lub poza nią. Zapowiadane są też znaczące wydarzenia z dziedziny muzyki, takie jak występ Ivona Pogorelicia w NOSPR (wpis z dn. 15.06.2017). O zaangażowaniu autorki w tę działalność świadczy fakt, że 
prowadzi ona również dwa blogi o muzyce poważnej na angielskojęzycznej platformie mikroblogowej tumblr: Treasures of Polish music oraz Karol Kurpiński forever.

Wpisy utrzymane są w tonie swobodnej pogawędki, np.: „Może kiedyś nawet zrobię wpis o braciach Marx, bo czemu nie...” (wpis z dnia 21.03.2018), „To by było na tyle proszę państwa, pozdrawiam!”, „Trzymajcie się, najnowszy porządny wpis już prawie gotowy" (wpis z dnia 21.03.2018) itd., itp. Zauważyć można, że ferowanie estetycznych wyroków przychodzi autorce z dużą łatwością, np.: „Nie ma tu koncertu na harfę Alberta Ginastery z 1965 roku, gdyż on jest okropny i dosłownie od słuchania rozbolała mnie głowa" (wpis z dnia 21.03.2018).

Dowodu na to, że możliwe jest pogodzenie zamiłowania do muzyki poważnej z innymi rodzajami sztuki dźwięków, dostarcza blog Placówka postępu (https:// placowkapostepu.wordpress.com/). Jego tematyka określona została następująco: „muzyka klasyczna dla początkujących. Muzyka rockowa dla średniozaawansowanych".

Blog ten wyróżnia się spośród innych tu analizowanych znacznie swobodniejszym językiem wypowiedzi. Jest on niemal potoczny, co związane jest zapewne zarówno z młodym wiekiem autora (27 lat), jak i z faktem, że zależy mu na tym, by nie zrazić do muzyki klasycznej osób, które do tej pory nie miały okazji się z nią zetknąć na dłużej. Autor stara się o takie zaprezentowanie muzyki poważnej, które może zainteresować miłośnika muzyki innego rodzaju. Pisze na przykład o muzyce klasycznej „zakamuflowanej” (własne określenie autora) w piosenkach pop oraz o inspiracjach, jakie z muzyki klasycznej czerpał Freddie Mercury, tworząc dla zespołu Queen. Jeana Sibeliusa przedstawia zaś jako „najważniejszego, do pojawienia się gitarzysty A-ha Påla Waaktaara, skandynawskiego kompozytora" (wpis $\mathrm{z}$ dnia 30.07.2017).

Jest to blog, na którym nowe wpisy pojawiają się najrzadziej z analizowanych: co miesiąc lub nawet co dwa miesiące. Nie wpływa to jednak negatywnie na jego popularność: dnia 29 marca 2018 r. na liczniku odwiedzających widniała liczba 355458.

\section{Podsumowanie}

Internet uznaje się za jedno z najważniejszych „środowisk życia” współczesnego człowieka, co potwierdza fakt, że do cyberprzestrzeni przenosi się całkowicie lub częściowo wiele działań. Jednym z nich jest upowszechnianie kultury. W złożoność zjawisk związanych z wirtualną aktywnością współczesnego człowieka wpisuje się blogowanie. Stanowi ono nowy sposób realizacji uniwersalnych potrzeb ludzkich w zakresie kontaktów społecznych, rozrywki, zdobywania informacji, samorozwoju i twórczości (Barani 2009). Istnieją jednak także znaczące różnice, które nakazują wyjście w analizach blogów poza proste analogie ze światem realnym. Przede 
wszystkim grupa, z którą utrzymywany jest kontakt, może być bardzo duża i bardzo zróżnicowana (na skalę, na jaką nie byłoby to możliwe w świecie realnym). Charakter kontaktów - jednocześnie publiczny i prywatny - także nie ma swojego odpowiednika w realnym świecie.

Jednocześnie blogi w znaczący sposób różnią się od innych form przekazu w Internecie. Pod pewnymi względami bardziej przypominają świat realny niż na przykład fora dyskusyjne czy czaty. Istotne znaczenie ma tu brak anonimowości piszącego, który zawsze w pewien sposób przedstawia się czytelnikom, a niekiedy jest znany także spoza Internetu. Forma bloga narzuca także regularność kontaktu i długi czas jego trwania - zwykle co najmniej kilka lat.

Blogi o muzyce poważnej nawet na tle innych blogów są zjawiskiem specyficznym. Tematyka artystyczna generuje stosunkowo niewiele sytuacji konfliktowych, zwłaszcza że niektóre osoby czytające nie czują się kompetentne, dopiero zdobywają wiedzę w danej dziedzinie. Sam fakt pisania i czytania o sztuce pozwala oczekiwać wysokiego poziomu ewentualnej dyskusji, zgodnie z powszechnym przekonaniem, że „sztuka łagodzi obyczaje”. Debata jest znacznie spokojniejsza niż na forach internetowych czy czatach. Blogi zbliżają Internet do świata realnego.

Prowadzenie bloga to aktywność stymulująca kreatywność autora, inspirująca go do systematycznego, wszechstronnego rozwoju w wybranej dziedzinie. Ułatwia nawiązywanie kontaktów, poznawanie ludzi o zbliżonych zainteresowaniach i podobnym trybie życia. Specyfika Internetu sprawia, że możliwe jest pisanie o wiele bardziej swobodne pod względem formalnym i językowym, nie obowiązują tu tradycyjne gatunki dziennikarskie, z czego chętnie korzysta także uznana dziennikarka Dorota Szwarcman. Blog sugeruje konwencję pogawędki, wymiany myśli. Jednocześnie blogi stanowią współczesną formę publicystyki i jako takie są świadectwem swoich czasów, także w dziedzinie kultury.

Podjęty temat jest obecnie bardzo aktualny, a jednocześnie słabo zbadany. W związku z tym zarysowuje się wiele interesujących pól badawczych: twórczy potencjał Internetu; Internet jako nowa forma upowszechniania kultury; blogi o sztuce jako inspiracja do samorozwoju i kreatywności autorów i odbiorców. Ciągły rozwój Internetu sprawia, że jeszcze przez długi czas tematu tego nie będzie można uznać za dobrze poznany.

\section{Bibliografia}

Barani K. (2009) Rola więzi online w życiu społecznym człowieka w: Psychologiczne konteksty Internetu, B. Szmigielska (red.), Kraków, Wydawnictwo WAM, s. 103-118.

Bassa A. (2016) Blogi i portale literackie we Francji. Nowe formy rekomendacji i debaty o ksiq̨żkach w: Nie tylko salon. Wspólnotowe formy życia literackiego, E. Łukaszczyk, K. Wierzbicka-Trwoga (red.), Warszawa, Wydawnictwo DiG, s. 101-108. 
Galewska-Kustra M. (2007) Studium przypadku w: K. J. Szmidt, Pedagogika twórczości, Gdańsk, GWP, s. 360-369.

Isaksen S. G., Lauer K., Ekvall G., Britz A. (2001), Perceptions of the best and worst climates for creativity: Preliminary validation evidence for the Situational Outlook Questionnaire, "Creativity Research Journal", 2, s. 171-184.

Keen A. (2007) Kult amatora. Jak Internet niszczy kulturę, Warszawa, Wydawnictwa Akademickie i Profesjonalne.

Karkowski M., Pawłowska K. (2009) Klimat dla kreatywności w miejscu pracy, „Bezpieczeństwo Pracy - Nauka i Praktyka", nr 2, s. 18-20.

Karwowski M. (2003) Klimat dla kreatywności w: Dydaktyka twórczości. Koncepcje - problemy - rozwiq̨zania, K. J. Szmidt (red.), Kraków, Oficyna Wydawnicza „Impuls”, s. 229-248.

Karwowski M (2009) Klimat dla kreatywności: koncepcje, metody, badania, Warszawa, Centrum Doradztwa i Informacji Difin.

Kozielecki (2008) Psychologia w wielkim świecie, Warszawa, Wydawnictwo Akademickie „Żak”.

Modrzejewska-Świgulska M. (2007) Teorie twórczości codziennej w: K. J. Szmidt, Pedagogika twórczości, Gdańsk, Gdańskie Wydawnictwo Psychologiczne, s. 160-164.

Nęcka E. (2016) Psychologia twórczości, Sopot, GWP.

Po premierze napisano - Księżniczka czardasza (2018), „Opera Café”, nr 41, s. 8-9.

Popek S. (2001) Człowiek jako jednostka twórcza, Lublin, Wydawnictwo Uniwersytetu Marii Curie-Skłodowskiej.

Rogowska M. (2013) Koncepcja kreatywnego miasta w teorii i praktyce, „Prace Naukowe Uniwersytetu Ekonomicznego we Wrocławiu”, nr 320, s. 156-165.

Sarowski Ł. (2017) Od Internetu Web 1.0 do Internetu Web 4.0 - ewolucja form przestrzeni komunikacyjnych w globalnej sieci, „Rozprawy Społeczne”, t. 11, s. 32-39.

Schulz R. (1990) Twórczość. Społeczne aspekty zjawiska, Warszawa, PWN.

Sołowiej J. (1997) Psychologia twórczości, Gdańsk, Wydawnictwo Uniwersytetu Gdańskiego.

Szuman S. (1975) O sztuce i wychowaniu estetycznym, Warszawa, WSiP.

Szmidt K. J. (2007) Pedagogika twórczości, Gdańsk, GWP. 


\section{Netografia}

https://szwarcman.blog.polityka.pl/

https://www.facebook.com/pg/blogerka.klasycznie.muzyczna/

http://po-klawiszach.blogspot.com/

https://placowkapostepu.wordpress.com/

Blog Doroty Szwarcman „Co w duszy gra” nominowany do Gwarancji Kultury 2015!, artykuł na oficjalnej stronie internetowej tygodnika „Polityka”, 09.04.2015, https://www.polityka.pl/opolityce/1615305,1,blog-doroty-szwarcman-co-w-duszygra-nominowany-do-gwarancji-kultury-2015.read [dostęp: 24.03.2018].

Film promocyjny Festiwal Opera Rara 2018 poleca Nadia Attavanti!, https:// www.youtube.com/watch?v=lJcByLkqXJ4 [dostęp: 24.03.2018] 